\title{
Comparison between Oligoryzomys nigripes and $O$. flavescens by RAPD and genetic diversity in $O$. nigripes (Rodentia, Cricetidae)
}

\author{
Mossi, AJ. ${ }^{a}$, Coppini, VJ. ${ }^{b}$, Slaviero, LB. ${ }^{c}$, Kubiak, GB. ${ }^{c}$, Lerin, LA. ${ }^{d}$, Oliveira, JV. ${ }^{d}$, \\ Cherem, JJ. ${ }^{e}$, Marinho, JR. ${ }^{c}$ and Cansian, RL. ${ }^{c *}$ \\ ${ }^{a}$ Universidade Federal da Fronteira Sul - UFFS, Av. Dom João Hoffmann, 313, CEP 99700-000, Erechim, RS, Brazil \\ ${ }^{\mathrm{b}}$ Geonature, Comércio e Serviços Ambientais Ltda, Av. Tiradentes, 516, sala 2, CEP 99700-000, Erechim, RS, Brazil \\ 'Universidade Regional Integrada do Alto Uruguai e das Missões - URI, Campus de Erechim, \\ Av. 7 de Setembro, 1621, CEP 99700-000, Erechim, RS, Brazil \\ ${ }^{\text {d} D e p a r t a m e n t o ~ d e ~ E n g e n h a r i a ~ Q u i ́ m i c a ~ e ~ d e ~ A l i m e n t o s, ~ U n i v e r s i d a d e ~ F e d e r a l ~ d e ~ S a n t a ~ C a t a r i n a ~-~ U F S C, ~}$ \\ Campus Universitário Reitor João David Ferreira Lima, Rua Delfino Conti, s/n, Trindade, \\ CEP 88040-900, Florianópolis, SC, Brazil \\ ${ }^{\text {e}}$ Caipora Cooperativa para Conservação da Natureza, Av. Desembargador Vitor Lima, 260/513, \\ Carvoeira, CEP 88040-400, Florianópolis, SC, Brazil \\ *e-mail: cansian@uricer.edu.br
}

Received: August 21, 2012 - Accepted: April 11, 2013 - Distributed: August 31, 2014

(With 4 Figures)

\begin{abstract}
The genus of Oligoryzomys includes species of small size, morphologically similar, which may impede taxonomic identification, mainly between $O$. flavescens (Waterhouse, 1837) and O. nigripes (Olfers, 1818). The main objective of this work was to investigate whether the RAPD markers are capable of genetically differentiating the specimens $O$. nigripes and O. flavescens, coming from Rio Grande do Sul (RS) and Santa Catarina (SC) states, and also to estimate the genetic variability among populations of $O$. nigripes, with the Uruguay River as a geographical barrier. For this purpose, samples were collected in fragments of forests situated in the North of RS, at FLONA (Floresta Nacional de Passo Fundo) and in fragments from SC, close to the Uruguay River. The karyotyping of two samples for each species was carried out and compared using the RAPD technique together with non- karyotyped individuals. Samples of $O$. nigripes presented $2 \mathrm{n}=62 ; \mathrm{NA}=82$, with submetacentric arms on the largest chromosomes, while samples of $O$. flavescens showed $2 \mathrm{n}=64 ; \mathrm{NA}=66$, with the largest chromosomes presenting acrocentric morphology, making such a result the main difference between the species. The analysis was able to detect two distinct groups, being the first one with karyotyped $O$. flavescens and the second with karyotyped $O$. nigripes. Identification afforded 211 loci, among them $181(85.78 \%)$ polymorphic. The Jaccard similarity coefficient was in the range of 0.45 to 0.87 . The UPGMA and Main Coordinate Analysis techniques demonstrated the existence of heterogeneous genetics among populations, but did not separate them completely in terms of geographical standards, and they are not influenced by the Uruguay River, which did not act as an efficient barrier.
\end{abstract}

Keywords: cytogenetics, RAPD, Oligoryzomys, molecular markers.

\section{Comparação entre Oligoryzomys nigripes e O. flavescens e diversidade genética em O. nigripes (Rodentia, Cricetidae) por RAPD}

\section{Resumo}

O gênero Oligoryzomys inclui espécies de tamanho pequeno, morfologicamente semelhantes, com difícil identificação taxonômica, principalmente entre $O$. flavescens e $O$. nigripes. O objetivo principal deste trabalho foi investigar se os marcadores RAPD são capazes de diferenciar geneticamente as amostras de $O$. nigripes e $O$. flavescens, oriundas do Rio Grande do Sul (RS) e Santa Catarina (SC) e também para estimar o variabilidade genética entre populações de $O$. nigripes, tendo o rio Uruguai como uma barreira geográfica. Para este fim, as amostras foram coletadas em fragmentos florestais situados no Norte do RS, na FLONA (Floresta Nacional de Passo Fundo) e em fragmentos florestais de SC, próximos ao Rio Uruguai. O cariótipo de duas amostras de cada espécie foi realizado e comparado com a técnica RAPD em conjunto com indivíduos não cariotipados. As amostras de $O$. nigripes apresentaram $2 \mathrm{n}=62, \mathrm{NA}=82$, com braços submetacêntricos nos cromossomos maiores, enquanto que as amostras de $O$. flavescens mostraram $2 \mathrm{n}=$ $64, \mathrm{NA}=66$, com os maiores cromossomos apresentando morfologia acrocêntrica, tornando tal resultado a principal diferença entre as espécies. As análises por RAPD foram capazes de detectar dois grupos distintos, sendo o primeiro 
com O.flavescens cariotipados e o segundo com $O$. nigripes cariotipados. Foram avaliados 211 loci, e entre eles 181 $(85,78 \%)$ foram polimórficos. O coeficiente de similaridade de Jaccard variou de 0,45 a 0,87 . A análise por UPGMA e análise de coordenadas principais demonstraram a existência de heterogeneidade genética entre as populações, mas não foi possível separá-las completamente em termos de padrões geográficos, e estas não são influenciadas pelo rio Uruguai, o qual não agiu como uma barreira eficiente.

Palavras-chave: citogenética, RAPD, Oligoryzomys, marcadores moleculares.

\section{Introduction}

The genus of Oligoryzomys includes 18 species of cricetid rodents of small size distributed in South and Central America (Musser and Carleton 2005, Weksler and Bonvicino 2005). In the South Brazilian region, two species are known: O. nigripes (Olfers, 1818) (including O. delticola, Thomas (1917) and O. eliurus, Wagner (1845 as synonymous) and $O$. flavescens (Waterhouse, 1837).

Oligoryzomys nigripes presents wide geographical distribution, with occurrence in the Atlantic Forest, from Pernambuco to Rio Grande do Sul, and in the south part of Cerrado, Distrito Federal and Minas Gerais and São Paulo states, besides Uruguay and some parts of Argentina and Paraguay. Oligoryzomys flavescens occurs in Atlantic Forest, from Bahia to Rio Grande do Sul states, and in forests of Cerrado of Central Brazil as well as in Uruguay, Argentina, Paraguay and Bolivia (Weksler and Bonvicino, 2005).

These two species present great similarity regarding external morphology which may seriously hinder correct identification (Weksler and Bonvicino 2005; Paresque et al., 2007). In such cases however, morphological characteristics and karyotype analysis have been employed as a tool to elucidate taxonomical problems through the establishment of species-specific karyotype (Bonvicino and Geise 1995; Paresque et al., 2004; Pereira and Geise, 2007).

Oligoryzomys nigripes presents a basic karyotype with $2 n=62$ and number of autosomal arms (NA) varying from 78 to 82 (Weksler and Bonvicino, 2005), having been registered with $2 \mathrm{n}=61$ (Andrades-Miranda et al., 2001; Paresque et al., 2007). Oligoryzomys flavescens presents greater variation of chromosomes number, with $2 \mathrm{n}=64$ 68, and NA $=66-70$ (Brum-Zorrilla et al., 1988; Aniskin and Volobouev, 1999; Weksler and Bonvicino, 2005).

Besides cytogenetic data, molecular markers have been widely used to delineate and compare populations in their natural environment, as well as their evolutionary rates and parental levels, relevant parameters for conservation in terms of geographical level and involved organisms (Silva and Patton, 1998). Furthermore, these markers may represent an alternative to identification of non-karyotyped specimen of Oligoryzomys. Only a few works are available in the open literature concerning the genetic relations among and inside Oligoryzomys species. Dickerman and Yates (1995) and Perini et al. (2004), using electrophoretic protein analysis, observed little difference among species of Oligoryzomys and Chiappero et al. (1997), using the same technique, did not find a correlation between genetic and geographic distances among the populations evaluated. Myers et al. (1995), in studying the cytochrome b sequence, also found little evidence in the difference among Oligoryzomys populations investigated. Trott et al. (2007) analysed the diversity and genetic relations inside and among species of the genus Oligoryzomys and observed considerable differences among populations and species thus indicating the presence of a great genetic variety among the taxa of Oligoryzomys investigated. Nevertheless, grouping analysis employing the genetic distance method of Nei did not correlate genetic heterogeneity of species and populations with geographical areas.

In this context, the main goal of this work was to evaluate the ability of RAPD (random amplified polymorphic DNA) molecular markers to genetically differentiate the species $O$. nigripes and $O$. flavescens, to estimate the genetic variability of $O$. nigripes populations, having the Uruguay River as a geographical boundary between populations.

\section{Material and Methods}

\subsection{Species and investigating area}

In this work, 44 specimen of $O$. nigripes and 2 of $O$. flavescens coming from the rivers Alpestre $\left(27^{\circ} 04^{\prime} 49^{\prime}\right.$ 'S-

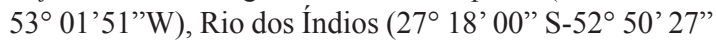
W), Erechim (Horto Florestal, $27^{\circ} 38^{\prime}$ 03' S-52 $12^{\circ}$ ' 26" W) and Mato Castelhano (FLONA Passo Fundo, $28^{\circ} 16^{\prime}$ 42 " S-52 $2^{\circ} 11$ ' 30" W), in Rio Grande do Sul state, and from Chapecó (border of Uruguay river, $27^{\circ} 05^{\prime}$ 04" S-52 ${ }^{\circ}$ 37' 06" W), in Santa Catarina state was used (Figure 1). One Euryoryzomys russatus individual was included in the analysis for external comparison, collected in Erechim (Horto Florestal, $27^{\circ} 38^{\prime} 03$ " S-52 $2^{\circ} 16^{\prime} 26^{\prime \prime} \mathrm{W}$ ).

The specimens submitted to karyotyping are deposited in the Regional Museum of Alto Uruguay (MuRAU ZOO 113 and 114 to $O$. nigripes, ZOO 115 and 116 to O. flavescens), Universidade Regional Integrada, Erechim (RS). The specimens collected in Chapecó (SC) and Alpestre (RS), were kindly supplied by the Collection of Mammals of the Department of Ecology and Zoology of Universidade Federal de Santa Catarina, Florianópolis (SC), and Scientific Collection of Universidade Regional de Blumenau (FURB), Blumenau (SC), respectively.

Collecting at Chapecó (SC) city was performed at the border of Uruguay River, and in the cities of Rio do Índios and Alpestre, it was carried out at the opposite border side, in Rio Grande do Sul state. Besides such data, samples were taken from specimens belonging to Erechim and Mato Castelhano, with these populations much further from each other compared to those next to the Uruguay River (75 and $140 \mathrm{Km}$, respectively). These captures and collections are in accordance with license number 15224-1 - IBAMA/ICMBio. 


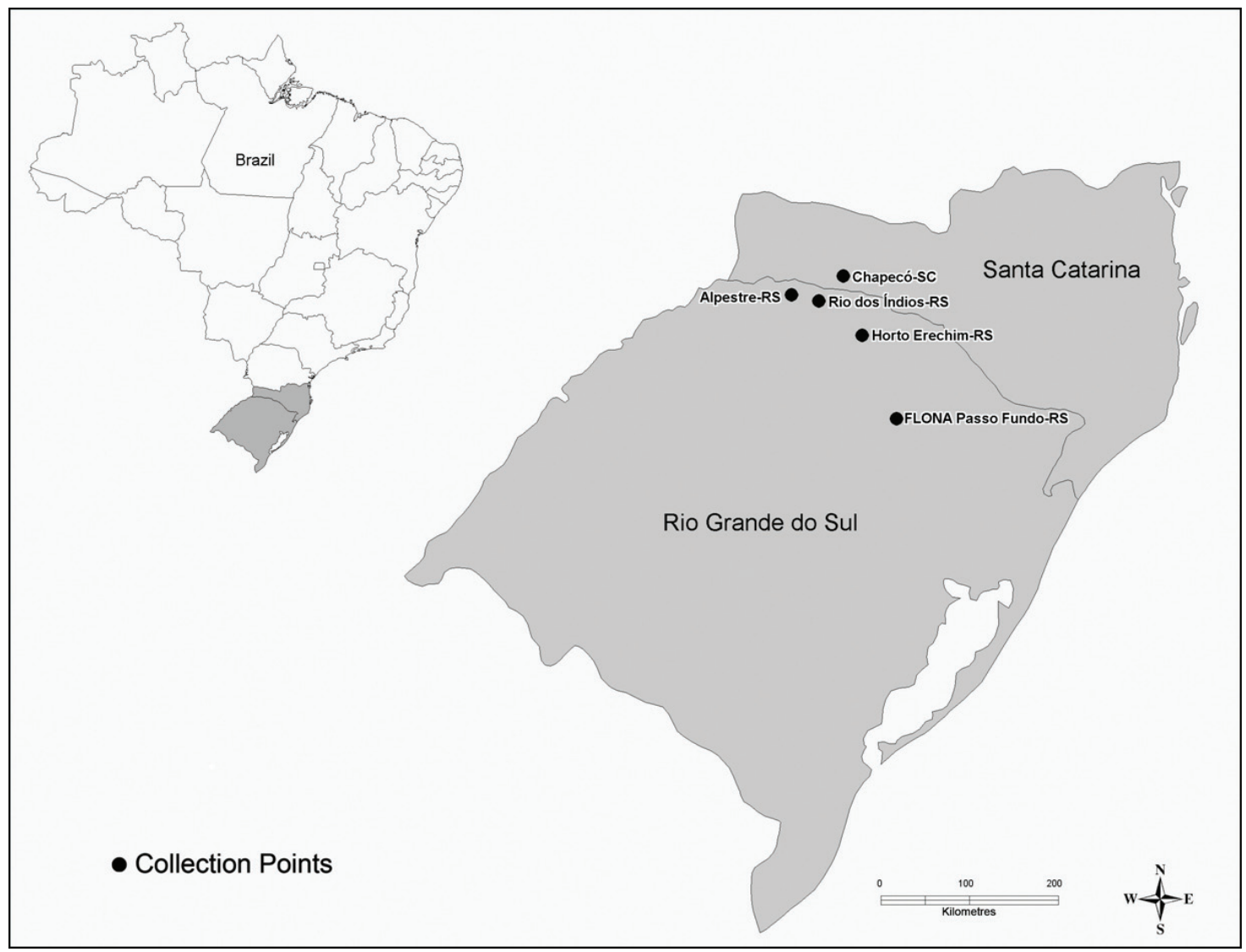

Figure 1. Geographical location of the collecting process (Passo Fundo, Erechim, Rio dos Índios and Alpestre at RS and Chapecó at SC).

\subsection{Karyotype cytogenetic analysis}

Two specimens of $O$. nigripes and two from $O$. flavescens were submitted to karyotyping. The metaphases were obtained from direct preparation of osseous marrow, according to Ford and Hamerton (1956) and Guerra and Souza (2002). Metaphase preparations were obtained from bone marrow, after in vivo injection of a $0.1 \%$ colchicine solution $(1 \mathrm{~mL} / 100 \mathrm{~g}$ of body weight). Cells were suspended in a $0.075 \mathrm{M} \mathrm{KCl}$ solution for $30 \mathrm{~min}$ at $37^{\circ} \mathrm{C}$, fixed in $3: 1$ methanol: acetic acid, spread onto clean slides and air-dried. The resulting material was colored in buffer phosphateGiemsa solution, at the ratio of 3:1, during $10 \mathrm{~min}$, washed with distilled water, and left dry at ambient temperature. At least 20 metaphases per individual were analysed to define the diploid and fundamental numbers. The karyotype were determined on the base of the works of Sbalqueiro et al. (1991), Andrades-Miranda et al. (2001), Paresque et al. (2004) and Pereira and Geise (2007).

\subsection{DNA extraction and molecular analysis}

Tissue samples were obtained from an ear fragment of the individuals and the genetic material was extracted following the protocol described by Medrano et al. (1990), replacing $\mathrm{NaCl}$ by chloroform:isoamyl alcohol 24:1. Amplification of RAPD was carried out as described by Levi (1993), with some modifications: reaction buffer $(50 \mathrm{mM}$ Tris- $\mathrm{HCl} \mathrm{pH}$ 9.0; $50 \mathrm{mM} \mathrm{KCl} ; 0.5 \%$ Triton-X 100), dNTPs (200mM of each), $0.2 \mu \mathrm{M}$ of primer, $3 \mathrm{mM}$ of $\mathrm{MgCl}_{2}, 80 \mathrm{ng}$ of DNA and $1.5 \mathrm{U}$ of Taq DNA polymerase. Amplification was accomplished in a thermocycler (MJ Research Inc.). The amplification process was as follows: $3 \mathrm{~min}$ at $92{ }^{\circ} \mathrm{C}, 40$ cycles of $1 \mathrm{~min}$ at $92^{\circ} \mathrm{C}, 1 \mathrm{~min}$ at $36^{\circ} \mathrm{C}$ and $2 \min$ at $72^{\circ} \mathrm{C}$. Then, after 3 min at $72{ }^{\circ} \mathrm{C}$ cooling at $4{ }^{\circ} \mathrm{C}$ up to samples taking. The electrophoretic separation was performed in agarose gel at 1.4\% TBE (trisma, boric acid and EDTA) buffer in a horizontal electrophoresis bath. As a molar mass marker, Lambda DNA cleaved with HindIII and EcoRI restriction enzymes was adopted. Fragment visualisation was carried out using ethidium bromide, observation performed in ultraviolet light and gels were digitally photographed. The primer belonging to seven kits from Operon Technologies was selected, with duplicate analysis, observing the intensity and reproducibility of the bands.

\subsection{Statistical analysis of experimental data}

Genetic variability was evaluated taking two data matrices, one of them built with 13 individuals identified as HO-15, O. flavescens, O. flavescens, O. nigripes, O. nigripes, IN-41, IN-42, IN-43, IN-39, CH-8, CH-11, FL-28 and HO-24 (HO - Horto Florestal, Erechim-RS; 
IN - Rio dos Índios-RS; CH - Chapecó-SC; FL - FLONA Mato Castelhano-RS), including $2 O$. nigripes and 2 $O$. flavescens karyotyped. The second evaluation was carried out considering 45 individuals with $44 O$. nigripes (CH - Chapecó-SC; HO - Horto Florestal, Erechim-RS; FL - FLONA Mato Castelhano-RS; AL - Alpestre-RS; IN - Rio dos Índios-RS) and 1 Euryoryzomys russatus (Horto Florestal, Erechim-RS).

Experimental data were obtained through determining presence or absence of 205 bands in the first case and 211 bands for the second, which comprised two matrices analysed by the computational code MVSP 3.1. The similarity dendrograms were built by the UPGMA algorithm (Unweighted Pair Group Method Using Arithmetic Averages), making use of the Jaccard similarity coefficient.

Genetic results were evaluated taking into account genetic diferences among individuals analysed, comparing, in the first case the karyotyped specimen with others and among them. In the second case, genetic differences were considered among populations, mainly for the Chapecó individuals with others and among them, in order to assess the genetic variability and to check whether the Uruguay River acts as a geographical boundary.

\section{Results and Discussion}

\subsection{Karyotype analysis}

The two karyotyped specimen of Oligoryzomys nigripes presented $2 \mathrm{n}=62 ; \mathrm{NA}=82$, due the variation in autosome fundamental number due to pericentric inversions (Yonenaga et al., 1976; Myers and Carleton, 1981). The Oligoryzomys flavescens showed $2 \mathrm{n}=64$; $\mathrm{NA}=66$, because the variation in diploid and autosome fundamental number which is related to the acrocentric or metacentric B chromosomes (Sbalqueiro et al., 1991). For O. nigripes, the largest chromosomes showed submetacentric arms, while for $O$. flavescens, the largest chromosomes are acrocentric, as already described by Sbalqueiro et al. (1991) and Almeida and Yonenaga-Yassuda (1991).

Paresque et al. (2007), in studying the karyotype variability of 85 specimens of $O$. nigripes, found $2 \mathrm{n}=$ 62 for 84 individuals and only one specimen, captured in the Espírito Santo state, presented $2 n=61$, due to a monosomy in the X chromosome. Andrades-Miranda et al. (2001), found similar results for most specimen studied, with $2 n=62$ and only one with $2 n=61$, also due to a monosomy in the $\mathrm{X}$ sexual chromosome. The same authors found a variation of $2 n=64$ to 67 for $O$. flavescens, a fact attributed to the presence of 0-3 accessories chromosome, described as B- chromosome.

\subsection{Genetic analysis among karyotyped and non- karyotyped individuals}

The primers selection revealed that OPA 19, OPB 8, OPF 3, OPF 11, OPF 12, OPF 14, OPW 1, OPW 9, OPW 17, OPW 19, OPY 6, OPY 16, OPY 19 and OPY 20 provided the best amplification results among samples analysed, then used for the amplification reactions of 13 individuals studied in the first analysis (HO-15, O. flavescens, O. flavescens, $O$. nigripes, $O$. nigripes, IN-41, IN-42, IN-43, IN-39, CH-8, CH-11, FL-28 and HO-24 (HO - Horto Florestal Erechim-RS; IN - Rio dos Índios-RS; CH - Chapecó-SC; FL - FLONA Mato Castelhano-RS). Considering the 13 individuals analysed, a total of 205 loci was identified, with $180(87.8 \%)$ being polymorphic. Trott et al. (2007) evaluated 75 polymorphic loci in species of the genus Oligoryzomys. The Jaccard similarity coefficient varied from 0.36 to 0,74 for the specimens analysed (Figure 2).

The UPGMA grouping analysis and Main Coordinate Analysis technique (MCA) allowed separating two distinct groups, as can be seen in Figure 3. The first group corresponds to the two karyotyped specimens identified as Oligoryzomys flavescens, and the second one represents the other individuals, including those karyotyped defined

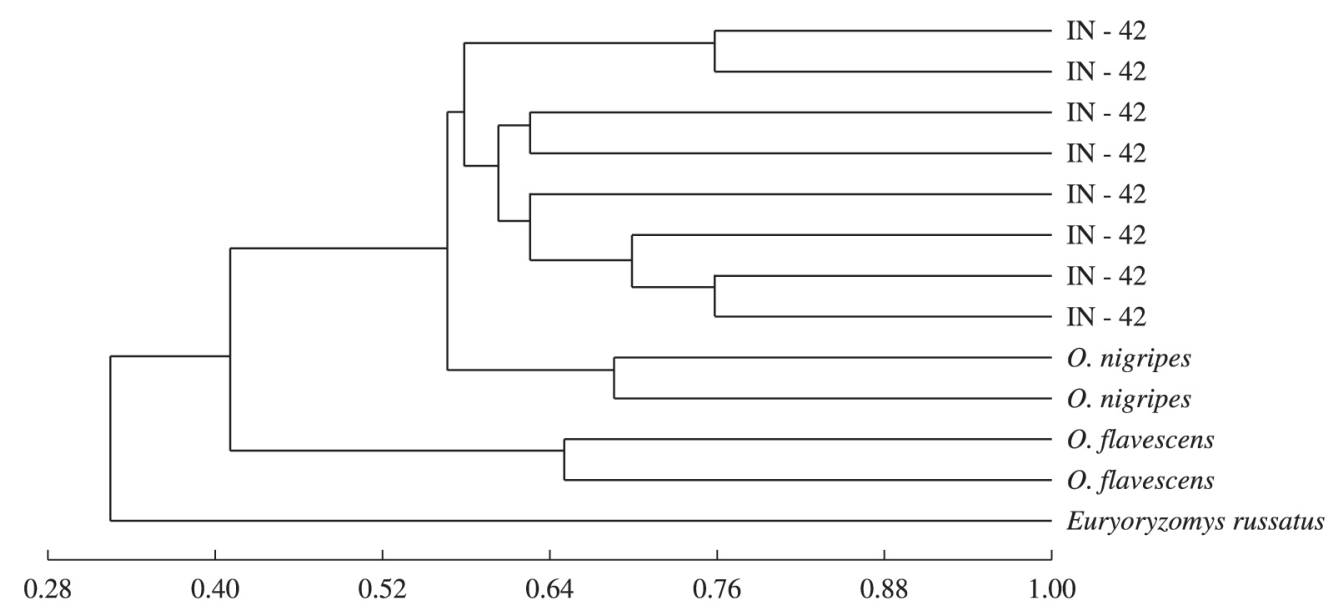

Figure 2. Dendrogram of 13 individuals of Oligoryzomys analysed by RAPD, using the Jaccard coefficient and UPGMA grouping technique (IN - Rio dos Índios-RS; CH - Chapecó-SC; HO - Horto Florestal Erechim-RS; FL - Flona Mato Castelhano -RS). 


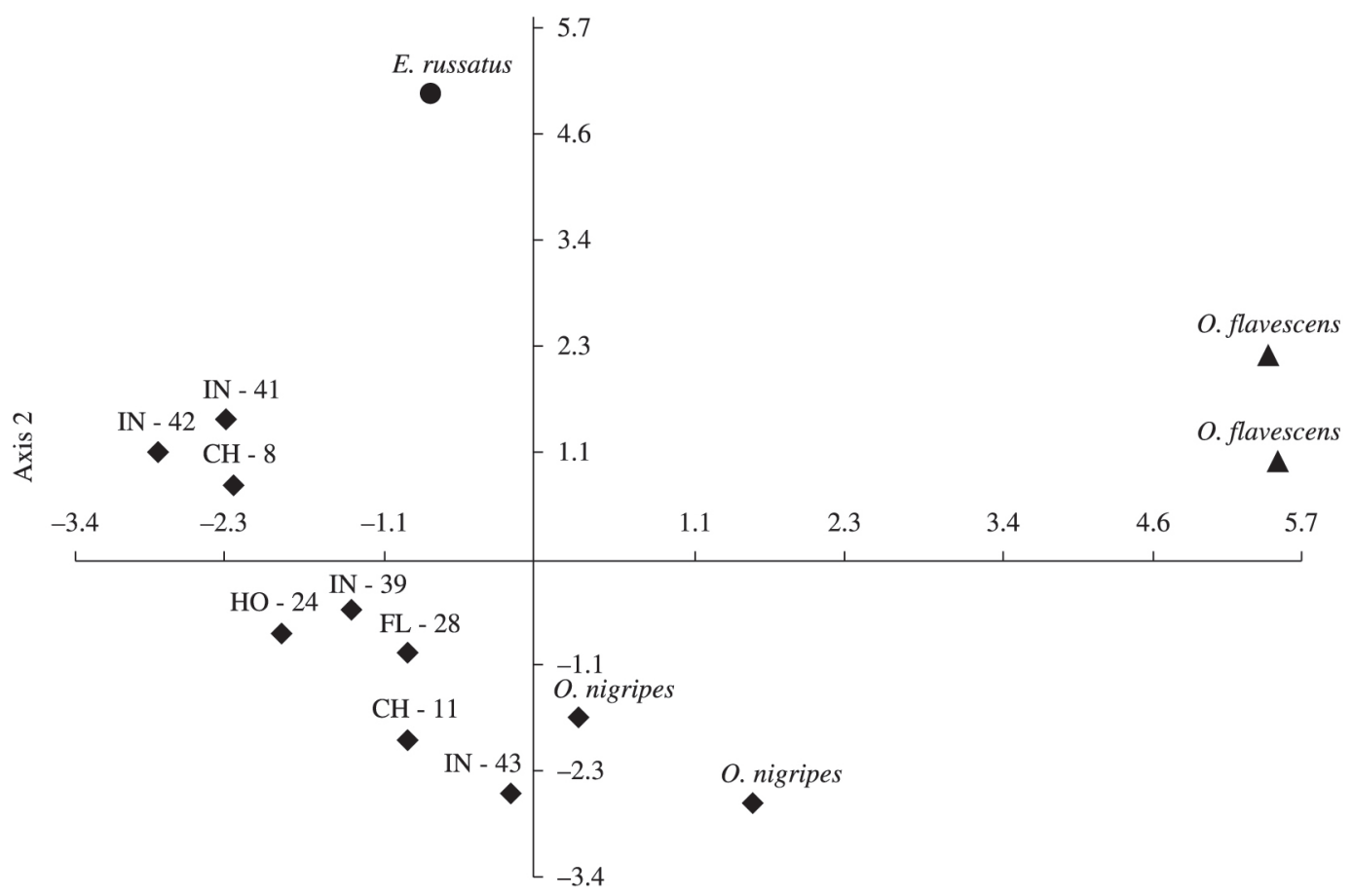

Axis 1

Figure 3. Main Coordinate Analysis of 13 individuals of Oligoryzomys (IN - Rio dos Índios-RS; CH - Chapecó-SC; HO Horto Florestal Erechim-RS; FL - Flona Mato Castelhano -RS).

as Oligoryzomys nigripes, a clear grouping between the members of this group not occurring with regard to the collecting area. This result indicates the capacity of the RAPD molecular markers in separating these two species, a result also obtained by Trott et al. (2007), allowing the identification of the individuals analysed in the second part of this work. Besides, a clear separation was noted for the individual Euryoryzomys russatus, collected at Horto Florestal Erechim-RS, and included in the analysis as external standard.

Trott et al. (2007), in investigating RAPD markers of the genus Oligoryzomys distributed in different biomes of Brazil, used a total of 75 polymorphic products simultaneously amplified in 151 specimens and observed that there is a great genetic variation among the taxa of Oligoryzomys investigated. However, they also noted that among the species of this genus, $O$. nigripes and $O$. flavescens presented the smallest genetic distance.

Although there is not an a priori hypothesis on how the species of a genus may arrange themselves, taxa investigated grouped, apparently, by their karyotype and to a certain extent by the geographical area occupied. There was a separation among karyotyped individuals, proven to be $O$. flavescens and $O$. nigripes, which corroborates the fact that the molecular markers based on RAPD are capable of genetically separating these two species. Such results are also in agreement with those found by Trott et al. (2007), because these authors were able to distinguish 6 species and 13 populations using RAPD markers, thus showing that the taxa of Oligoryzomys are genetically different.

\subsection{Population genetics analysis}

Of the 45 individuals analysed, 12 were captured at Horto de Erechim-RS, 5 from Rio dos Índios-RS, 14 at Chapecó-SC, 12 at Flona in Mato Castelhano-RS and 2 form Alpestre-RS. From the 45 individuals investigated, a total of 211 loci were identified, $181(85.78 \%)$ being polymorphic (Table 1 and 2). The population that presented the greatest number of loci was Chapecó (192), but the percentage of polymorphic bands was relatively different and smaller only for the Alpestre population (142 bands, $29.58 \%$ polymorphic), which may be explained in terms of the small sampling for this place.

The Jaccard similarity coefficient varied in the range of 0.45 to 0.87 for the populations analysed (see Figure 4). In this sense, a trend of individuals grouping was observed at each place, mainly regarding the population of Rio dos Índios, which, although formed by few specimens, most of them were very close to each other.

This trend can be clearly verified from the dendrogram produced by the Jaccard similarity coefficient. One group corresponds to almost the entire population of Rio dos Índios ( $80 \%$ of individuals), lacking only one specimen. The other groups showed a smaller trend to population grouping, with individuals distributed throughout the populations, though $58.3 \%$ of specimen for Horto, $66.6 \%$ at Flona and $57.1 \%$ for Chapecó were found grouped. The 
Table 1. Total fragment number and number of polymorphic fragments obtained for each primer used in the analysis of individuals of Oligoryzomys nigripes (Olfers, 1818).

\begin{tabular}{cccc}
\hline \multirow{2}{*}{ Primer } & \multirow{2}{*}{ Sequence (5' to 3') } & \multicolumn{2}{c}{ Total of individuals } \\
\cline { 3 - 4 } & & Total of bands & Polymorphic band \\
\hline OPA-19 & CAAACGTCGG & 12 & 12 \\
OPB-08 & GTCCACACGG & 20 & 19 \\
OPF-03 & CCTGATCACC & 14 & 13 \\
OPF-11 & TTGGTACCCC & 13 & 13 \\
OPF-12 & ACGGTACCAG & 13 & 05 \\
OPF-14 & TGCTGCAGGT & 19 & 16 \\
OPW-01 & CTCAGTGTCC & 13 & 11 \\
OPW-09 & GTGACCGAGT & 17 & 17 \\
OPW-17 & GTCCTGGGTT & 16 & 13 \\
OPW-19 & CAAAGCGCTC & 11 & 03 \\
OPY-06 & AAGGCTCACC & 15 & 12 \\
OPY-16 & GGGCCAATGT & 17 & 16 \\
OPY-19 & TGAGGGTCCC & 16 & 16 \\
OPY-20 & AGCCGTGGAA & 15 & 15 \\
& TOTAL & 211 & 181 \\
& $\%$ & 100 & 85,78 \\
\hline
\end{tabular}

Table 2. Total fragment number and number of polymorphic fragments obtained for each primer used in the five populations analysed of Oligoryzomys nigripes (Olfers, 1818) and number of individuals at each place. TB - total of bands; BPpolymorphic bands.

\begin{tabular}{|c|c|c|c|c|c|c|c|c|c|c|}
\hline & \multicolumn{2}{|c|}{ Chapecó } & \multicolumn{2}{|c|}{ Horto } & \multicolumn{2}{|c|}{ Flona } & \multicolumn{2}{|c|}{ Rio dos Índios } & \multicolumn{2}{|c|}{ Alpestre } \\
\hline \multirow{2}{*}{$\begin{array}{c}\text { NI* } \\
\text { Primer }\end{array}$} & \multicolumn{2}{|c|}{14} & \multicolumn{2}{|c|}{12} & \multicolumn{2}{|c|}{12} & \multicolumn{2}{|c|}{5} & \multicolumn{2}{|c|}{2} \\
\hline & TB & $\mathbf{B P}$ & TB & BP & TB & BP & TB & BP & TB & BP \\
\hline OPB 08 & 20 & 18 & 17 & 16 & 16 & 14 & 19 & 17 & 13 & 05 \\
\hline OPA 19 & 11 & 11 & 11 & 11 & 11 & 11 & 07 & 07 & 04 & 03 \\
\hline OPF 14 & 17 & 12 & 16 & 12 & 14 & 09 & 18 & 10 & 17 & 07 \\
\hline OPF 12 & 11 & 03 & 12 & 04 & 13 & 05 & 10 & 02 & 10 & 01 \\
\hline OPF 11 & 13 & 12 & 12 & 12 & 11 & 10 & 10 & 10 & 10 & 03 \\
\hline OPF 03 & 11 & 10 & 14 & 13 & 10 & 08 & 10 & 07 & 10 & 04 \\
\hline OPY 20 & 15 & 15 & 12 & 11 & 14 & 14 & 13 & 09 & 09 & 02 \\
\hline OPY 19 & 14 & 13 & 14 & 12 & 13 & 13 & 15 & 10 & 09 & 03 \\
\hline OPY 16 & 14 & 12 & 16 & 14 & 15 & 12 & 16 & 13 & 12 & 05 \\
\hline OPY 06 & 14 & 09 & 15 & 12 & 12 & 07 & 13 & 08 & 11 & 05 \\
\hline OPW 01 & 12 & 07 & 11 & 05 & 11 & 06 & 13 & 09 & 08 & 01 \\
\hline OPW 09 & 17 & 14 & 14 & 14 & 17 & 14 & 14 & 12 & 10 & 01 \\
\hline OPW 17 & 13 & 09 & 11 & 07 & 11 & 07 & 14 & 08 & 10 & 02 \\
\hline OPW 19 & 10 & 02 & 10 & 02 & 11 & 03 & 09 & 01 & 09 & 00 \\
\hline TOTAL & 192 & 147 & 185 & 145 & 179 & 133 & 181 & 123 & 142 & 42 \\
\hline$\%$ & 100 & 76,56 & 100 & 78,38 & 100 & 74,30 & 100 & 67,96 & 100 & 29,58 \\
\hline
\end{tabular}

*NI - Number of individuals.

individuals of Euryoryzomys russatus, included in the analysis as an external standard, kept a clear separation, even with a greater number of individuals analysed.

It is worth noticing the lack of genetic proximity between the populations of Chapecó (Santa Catarina state) and Alpestre and Rio dos Índios-RS, due to the geographical immediacy, despite being separated by the Uruguay River. Note also that the individuals of Alpestre are not genetically similar to those of Rio dos Índios, in spite of the geographical nearness of these two places.
The RAPD analysis performed in this work revealed a significant genetic heterogeneity among the taxa helping discriminate among the species of Oligoryzomys, a genus considered until now, to be composed of several little different species. Nevertheless, genetic relationships among populations of Oligoryzomys coming from such data seem not to be dependent on geographical distances nor influenced by rivers acting as reproductive barriers.

Trott et al. (2007) demonstrated that several diversity estimations presented considerable differences among the 


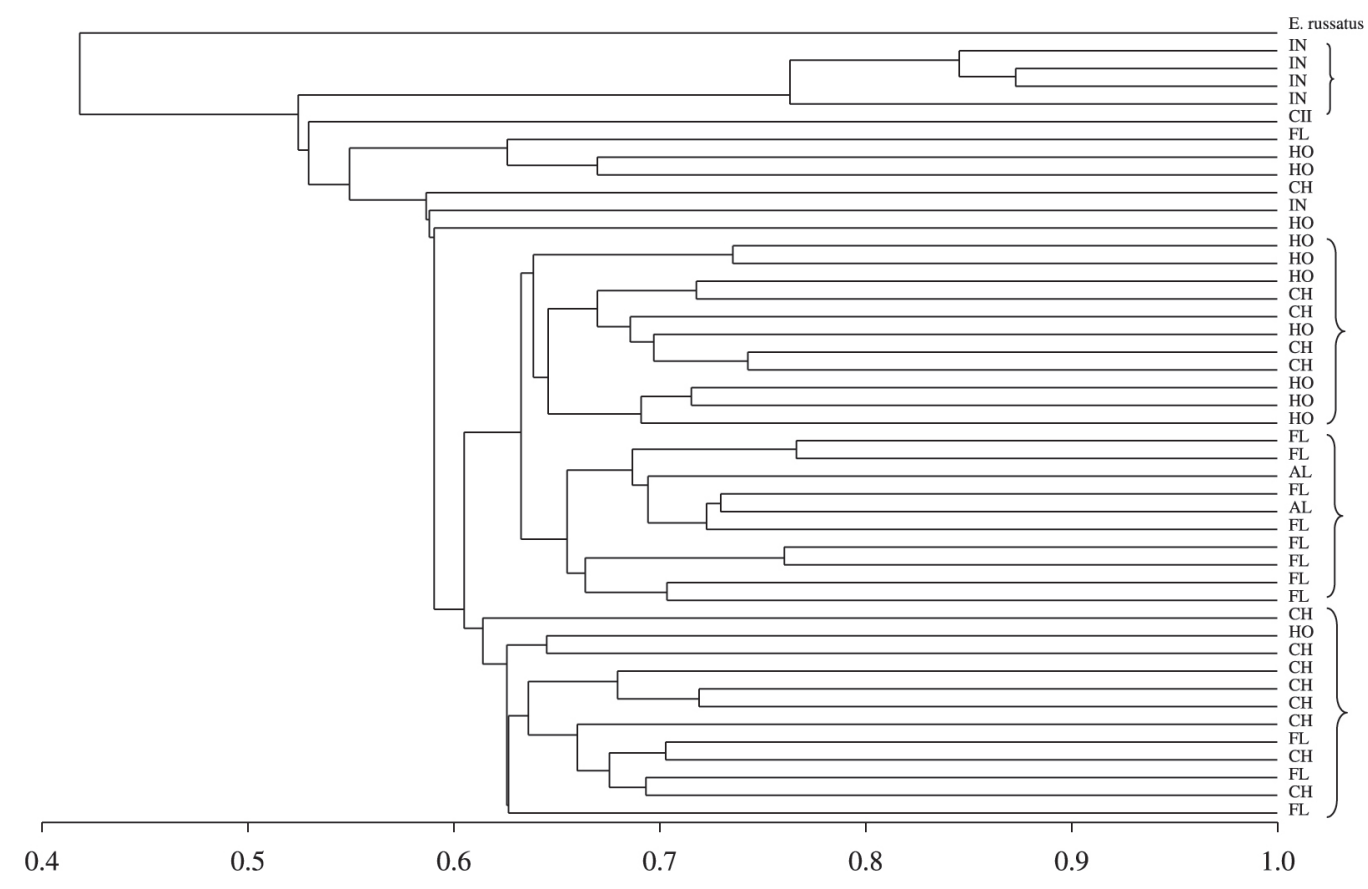

Figure 4. Dendrogram of the individuals analysed by RAPD, using the Jaccard coefficient and UPGMA grouping technique (CH - Chapecó-SC; HO - Horto Florestal Erechim-RS; FL - Flona Mato Castelhano-RS; AL - Alpestre-RS; IN - Rio dos Índios-RS).

species and populations, hence pointing to a great genetic variety among taxa of Oligoryzomys investigated. The grouping analysis using the genetic distance method by Nei, however, did not correlate the genetic heterogeneity of species and populations with the geographical areas, corroborating the results found in this work. Thus, it is possible that the relationships presented may be a result of a specific biology history of each species, like the population dimension in the past or the different strategies developed to explore and occupy the actual places (Trott et al., 2007). Furthermore, it was observed that rivers, like the Uruguay River, might not be a barrier for individuals migration and accordingly for genetic flux among populations. Thus, one should expect that the genetic similarity among individuals would be greater, with unclear separation among populations according to their occurrence regions.

\section{Conclusions}

The investigations performed in this work regarding genetic relationships among the species of Oligoryzomys based on molecules demonstrated that they are homogeneous (Trott et al., 2007). Investigations based on the electrophoresis analysis of proteins for the species of Oligoryzomys in attempt to search for a taxonomical classification and a relationship among the species demonstrated that the species are barely differentiated (Dickerman and Yates, 1995). Chiappero et al. (1997), also using enzymes to estimate the genetic flux among populations of Oligoryzomys flavescens coming from Argentina, detected the lack of isolation for a distance standard among populations. In another investigation performed by Myers et al. (1995) using cytochrome b gene sequence, several species of Oligoryzomys, little evidence of differentiation was found for the populations. In the present work, though the first analysis made by RAPD has separated Oligoryzomys flavescens and Oligoryzomys nigripes, the second one showed genetic heterogeneity among 5 populations studied, noting that complete separation through geographical distances was not achieved, with the exception of the Rio dos Índios-RS population, but the fact that only 5 individuals were employed does not allow a satisfactory conclusion to be drawn on the isolation of this population. The analysis also demonstrated that the populations are not influenced by the Uruguay River, i.e., it does not act as a barrier for efficient reproduction.

\section{Acknowledgements}

The authors wish to thank CNPq, FAPERGS and Secretaria de Ciência e Tecnologia-RS for the financial support and scholarships.

\section{References}

ALMEIDA, EJC. and YONENAGA-YASSUDA, Y., 1991. Pericentric inversion and sexual chromosome heteromorphisms in Oryzomys nigripes (Rodentia, Cricetidae). Caryologia, vol. 44, no. 1, p. 63-73. http://dx.doi.org/10.1080/00087114.1991.10797020.

ANDRADES-MIRANDA, J., OLIVEIRA, LFB., LIMA-ROSA, CAV., NUNES, AP., ZANCHIN, NIT. and MATTEVI, MS., 2001. Chromosome studies of seven species of Oligoryzomys 
(Rodentia: Sigmodontinae) from Brazil. Journal of Mammalogy, vol. 82, no. 4, p. 1080-1091. http://dx.doi.org/10.1644/15451542(2001)082<1080:CSOSSO >2.0.CO;2.

ANISKIN, VM. and VOLOBOUEV, VT., 1999. Comparative chromosome banding of two South-American species of rice rats of the genus Oligoryzomys (Rodentia, Sigmodontinae). Chromosome Research: an International Journal on the Molecular, Supramolecular and evolUtionary Aspects of Chromosome Biology, vol. 7, no. 7, p. 557-562. http://dx.doi.org/10.1023/A:1009245729902. PMid:10598571

BONVICINO, CR. and GEISE, L., 1995. Taxonomic status of Delomys dorsalis collinus Thomas, 1917 (Rodentia, Cricetidae) and description of a new karyotype. Zeitschrift fur Saugetierkunde, vol. 60 , p. 124-127.

BRUM-ZORRILLA, G., FRONZA, TG., WAINBERG, R., VIDALRIOJA, L. and ZWIRNER, N., 1988. Oryzomys flavescens and O. delticola chromosomes (Rodentia, Cricetidae) from Uruguay and Argentina. Caryologia, vol. 41, no. 3-4, p. 275-288. http:// dx.doi.org/10.1080/00087114.1988.10797868.

CHIAPPERO, MB., CALDERÓN, GE. and GARDENAL, CN., 1997. Oligoryzomys flavescens (Rodentia, Muridae): gene flow among populations from central-eastern Argentina. Genetica, vol. 101, no. 2, p. 105-113. http://dx.doi.org/10.1023/A:1018399308323. PMid:9465403

DICKERMAN, AW. and YATES, TL., 1995. Systematics of Oligoryzomys: Protein-electrophoretic analyses. Journal of Mammalogy, vol. 76, no. 1, p. 172-188. http://dx.doi. org/10.2307/1382326.

FORD, CE. and HAMERTON, JL., 1956. A colchicine, hypotonic citrate, squash sequence for mammalian chromosomes. Stain Technology, vol. 31, no. 6, p. 247-251.PMid:13380616.

GUERRA, M. and SOUZA, MJ., 2002. Como observar cromossomos: um guia de técnicas em citogenética vegetal, animal e humana. Ribeirão Preto: FUNPEC.

LEVI, A., 1993. Production of reliable randomly amplified polymorphic DNA (RAPD) markers from DNA of woody plants. HortScience, vol. 28, p. 1188-1190.

MEDRANO, JF., AASEN, E. and SHARROW, L., 1990. DNA extraction from nucleated red blood cells. BioTechniques, vol. 8, no. 1, p. 43. PMid:2182076.

MUSSER, GM. and CARLETON, MD., 2005. Superfamily Muroidea. In WILSON, DE. and REEDER, DM. (Eds.). Mammal species of the world: A taxonomic and geographic reference. $3 \mathrm{rd}$ ed. Baltimore: Johns Hopkins University Press. p. 894-1531.

MYERS, P. and CARLETON, MD., 1981. The species of Oryzomys (Oligoryzomys) in Paraguay and the identity of Azara's "Rat sixième ou Rat à Tarse Noir". Miscelaneous Publications of the Museum of Zoology University of Michigan, vol. 161, p. 1-41.

MYERS, P., LUNDRIGAN, B. and TUCKER, PK., 1995. Molecular phylogenetics of oryzomyine rodents: the genus Oligoryzomys. Molecular Phylogenetics and Evolution, vol. 4, no. 4, p. 372382. http://dx.doi.org/10.1006/mpev.1995.1035. PMid:8747294

PARESQUE, R., SILVA, MJJ., YONENAGA-YASSUDA, Y. and FAGUNDES, V., 2007. Karyological geographic variation of Oligoryzomys nigripes Olfers, 1818 (Rodentia, Cricetidae) from Brazil. Genetics and Molecular Biology, vol. 30, no. 1, p. 43-53. http://dx.doi.org/10.1590/S1415-47572007000100010.

PARESQUE, R., SOUZA, WP., MENDES, SL. and FAGUNDES, V., 2004. Composição cariotípica da fauna de roedores e marsupiais de duas áreas de Mata Atlântica do Espírito Santo, Brasil. Boletim de Museu de Biologia Mello Leitão, vol. 17, p. 5-33.

PEREIRA, LG. and GEISE, L., 2007. Karyotype composition of some rodents and marsupials from Chapada Diamantina (Bahia, Brasil). Brazilian Journal of Biology, vol. 67, no. 3, p. 509-518. http://dx.doi.org/10.1590/S1519-69842007000300016. PMid:18094834

PERINI, MV., WEIMER, TA., CALLEGARI-JACQUES, SM. and MATTEVI, MS., 2004. Biochemical polymorphisms and genetic relationships in rodents of the genera Oryzomys and Oligoryzomys (Sigmodontinae) from Brazil. Biochemical Genetics, vol. 42, no. 9-10, p. 317-329.

SBALQUEIRO, IJ., MATTEVI, MS., OLIVEIRA, LF. and SOLANO, MJV., 1991. B chromosome system in populations of Oryzomys flavescens (Rodentia, Cricetidae) from southern Brazil. Acta Theriologica, vol. 36, p. 193-199. http://dx.doi. org/10.4098/AT.arch.91-18.

SILVA, MN. and PATTON, JL., 1998. Molecular phylogeography and the evolution and conservation of Amazonian mammals. Molecular Ecology, vol. 7, no. 4, p. 475-486. http://dx.doi. org/10.1046/j.1365-294x.1998.00276.x. PMid:9628001

TROTT, A., CALLEGARI-JACQUES, SM., OLIVEIRA, LFB., LANGGUTH, A. and MATTEVI, MS., 2007. Genetic diversity and relatedness within and between species of the genus Oligoryzomys (Rodentia; Sigmodontinae). Brazilian Journal of Biology, vol. 67, no. 1, p. 153-160. http://dx.doi.org/10.1590/ S1519-69842007000100021. PMid: 17505763

WEKSLER, M. and BONVICINO, CR., 2005. Taxonomy of pigmy rice rats genus Oligoryzomys Bangs, 1900 (Rodentia, Sigmodontinae) of the Brazilian Cerrado, with description of two new species. Arquivos do Museu Nacional, vol. 63, p. 113-130.

YONENAGA, Y., FROTA-PESSOA, O., KASAHARA, S. and ALMEIDA, EJC., 1976. Cytogenetic studies on Brazilian rodents. Ciência e Cultura, vol. 28, no. 2, p. 202-211. 